University of Rhode Island

DigitalCommons@URI

Open Access Master's Theses

1992

\title{
A QUALITATIVE EXPLORATION OF IDENTITY DEVELOPMENT OF GAY AND LESBIAN UNDERGRADUATE STUDENTS
}

Myralee Peebles

University of Rhode Island

Follow this and additional works at: https://digitalcommons.uri.edu/theses

\section{Recommended Citation}

Peebles, Myralee, "A QUALITATIVE EXPLORATION OF IDENTITY DEVELOPMENT OF GAY AND LESBIAN UNDERGRADUATE STUDENTS" (1992). Open Access Master's Theses. Paper 1688.

https://digitalcommons.uri.edu/theses/1688

This Thesis is brought to you for free and open access by DigitalCommons@URI. It has been accepted for inclusion in Open Access Master's Theses by an authorized administrator of DigitalCommons@URI. For more information, please contact digitalcommons-group@uri.edu. 


\section{BF 724.3 \\ I3 \\ P424 \\ 1992}

A QUALITATIVE EXPLORATION OF IDENTITY DEVELOPMENT OF GAY AND LESBIAN

UNDERGRADUATE STUDENTS

BY

MYRALEE PEEBLES

A THESIS SUBMITTED IN PARTIAL FULFILLMENT OF THE REQUIREMENTS FOR THE DEGREE OF

MASTER OF SCIENCE

IN

HUMAN DEVELOPMENT, COUNSELING, AND FAMILY STUDIES

UNIVERSITY OF RHODE ISLAND

1992

27097846 


\begin{abstract}
This research explored, described, and related the experiences of gay and lesbian undergraduate students on one campus to existing theories of gay identity development. A sample of gay and lesbian students were interviewed, resulting in prevalent themes. The themes included campus climate, career concerns, classroom experiences, "coming out" experiences, fathers and mothers, first experiences, first relationships, gay men about gay men, on being "out of the closet," other-acceptance, parents, reasons for gayness, religion, and self-acceptance. Results showed that the environmental challenges of the campus exist which may affect the development of the student's identity of a gay self. Implications of the findings and recommendations for campus programming are included.
\end{abstract}




\section{Acknowledgements}

I extend gratitude to all who served on my committee:

Dr. Jayne Richmond, Chair, Dr. Wm. Lynn McKinney, Dr. Karen Schroeder, Dr. George Willis, and Dr. Kat Quina.

I extend a very big thank you and applaud the students who participated in the interviews. I am a better person for my time spent with each of you.

I thank all of my fellow graduate students... especially the "Thesis Lunch Bunch:" Anni, Claudia, Ceci, and Heidi! 


\section{Table of Contents}

Abstract.....................................................................................................

Acknowledgements....................................................................iii

Chapter One: The Problem.............................................................1

Chapter Two: Literature Review................................................9

Chapter Three: Methodology....................................................21

Chapter Four: Results/Findings.................................................26

Chapter Five: Summary...................................................................49

Appendix A: Consent Form ........................................................58

Appendix B: Support Resources Handout...............................59

Appendix C: Follow-up Questions.............................................60

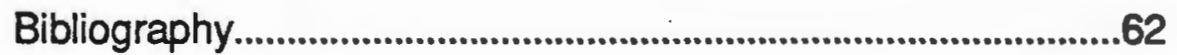




\section{Chapter One: The Problem}

For most students, the undergraduate college or university experience occurs during a time of physical, emotional, and intellectual growth and discovery. Students are searching for their sense of self and a place in their community and world; students may reshape their adolescent identities into more focused adult identities. One very important issue in the development of all students is that of their intimate and sexual relationships. This study explores the unique developmental issues of gay identity for traditional age gay and lesbian undergraduate students at a mid-size, public university.

College students leave their community high schools and enter a world in which there are a myriad of discoveries and growth opportunities. They are surrounded by new buildings, unfamiliar faces, and unexpected individual changes. The traditional student enters and leaves college in the awakening years of young adulthood. They bring to their campus family and cultural traditions unique to their individual experiences. They also bring their individual and personal needs for challenge and support. As recognition of diversity on college and university campuses increases, an understanding of the challenges faced by students of diverse populations is essential to meeting their needs.

The college experience provides different opportunities for exploration and comparison unique to each student. There are students who may feel particularly challenged: students with disabilities, students with ethnicities different from the majority, or female students in male-dominated academic majors, for example. Students whose sexual orientations differ may face a variety of unique challenges as well.

College and university environments are a microcosm of society. Campus climates tend to mirror the values and patterns of acceptance that exist in the 
larger society (Evans \& Wall, 1991). The options for gay and lesbian students to explore a core part of themselves may be absent if an environment denies their existence. According to Evans and Wall (1991, p.81), "The issues and concerns faced by lesbian and gay students have their roots in the very rigid assumptions of heterosexuality that pervade the residence hall environment." Although the same assumptions are made in society at large, the close quarters of a residence hall, combined with young adults searching for a sexual identity, usually intensify in an environment which presumes heterosexuality (Evans \& Wall, 1991). There is a lack of privacy, roommate dilemmas, and social activities that assume heterosexuality of the participants which may further push the gay and lesbian students to the side. The comfortable allowance of sharing feelings and relating to others may be a rare commodity.

Because "values and norms of our society have been generally antihomosexual, identity development of gays and lesbians involves integrating a stigmatized aspect of identity" (Hanley-Hackenbruck, 1989, p.22). Stigmatized environmental supports on a campus may include the social and residential aspects of the student's early life. Therefore, in "the interplay between (the environment) and the individual, the development of gay and lesbian identity differs greatly from the development of heterosexual identity" (HanleyHackenbruck, 1989, p. 24).

Though colleges and universities have begun to recognize these issues as important, gay and lesbian students have been educated, socialized, and housed in environments which are often not accepting of difference. These environments may change as a result of a recognition of special needs. An environment undergoing this change may pass through its own levels of development. The researcher describes possible transitional stages with a combination of terms used by the theorists discussed in this project: 
denial/oppression, awareness, tolerance, acceptance, integration/informed support, and celebration.

In a supportive environment, many activities during the undergraduate years encourage students to develop self-esteem and a distinct identity (Chickering, 1969). Given a nonsupportive environment for the gay and lesbian student, answering the question, "Who am 1?" can be especially difficult. According to generally accepted reports, $10 \%$ of the population is homosexual (Kinsey, Pomeroy, \& Martin, 1948). Applying this number to a college campus indicates there exists a significant number of students in its gay and lesbian community. This has many implications for a campus environment and its student development professionals.

All undergraduate students experience the complexities of behavioral change and growth. Student development professionals engage in the practice of enhancing that growth and development of the students. Gay and lesbian students may be as likely to deal with peer relations, family relations, career decisions, classroom environments, and self acceptance as any other student. However, students who take on the task of identifying themselves, either internally or externally, as gay or lesbian, face further challenges in their typically oppressive environment.

In other words, the challenge of typical gay identity development is compounded by the lack of informed support in their environment. This lack of support may be the result of ignorance and fear. Many professionals who work with students may be fearful of, or unaware of, the issues facing the gay or lesbian student. Added to this is the fear of students who are not gay and may not be comfortable with supporting their gay and lesbian peers. This lack of support may have disastrous results. According to a study commissioned by the Department of Health and Human Services, gay youth are two to three times 
more likely to attempt suicide than heterosexual youth, and up to $30 \%$ of teens who do commit suicide are gay or lesbian (Maguen, 1991).

Together these ideas suggest that a large number of students may struggle with a very important question in an environment which, in most cases, may deny their existence. On college campuses, student development practitioners do not seem to have an understanding of gay and lesbian students. The demands of these students reach beyond the understanding of basic theories. It is a crucial challenge for all student development practitioners to be aware of the specific nature of the needs of this sub-population. This requires recognition and awareness of the nature of the student's challenges, experiences, and needs.

The first comprehensive report on sexual orientation among Americans was the work of Kinsey, Pomeroy, and Martin (1948). Though his methodology remains controversial, the study resulted in quantitative information and a continuum of homosexual/heterosexual classification. There was a fundamental missing link in the literature available to the researcher on issues of identity development and the campus environment as they relate to gay and lesbian students. Most research seemed to explore numerical data and postulates of developmental theories applied to lesbians and gays. One early theory, (Grace, 1979) spans development from emergence to self-definition and reintegration, another (Coleman, 1982) begins with preconscious awareness and ends with integration. A third theory (McDonald, 1982) includes awareness to positive gay identity. These three theories will be further explored in the literature review. Two models of identity formation are used as the basis for understanding in this research: Cass (1979) and Kus (1988).

For students in a minority group, the identity process can be a struggle. Cass (1979) discusses the meaning of "identity" in terms of homosexuality: It 
may refer to "...1. defining oneself as gay; 2. a sense of self as gay; 3 . an image of self as homosexual; or 4. consistent behavior in relation to homosexual-related activity" (p. 220). Students may refer to themselves as gay or lesbian based on any of these meanings according to their level of development. Cass (1979, pp. 222-234) also proposed that there are six stages of development which gay and lesbian individuals experience in order to adopt an identity of "homosexual" that is integrated within their overall concept of self. (These stages as described below are a partial basis of analysis for the data as it will be discussed later.)

I. Identity Confusion: recognition that some thoughts, feelings, or behaviors might be homosexual in nature

II. Identity Comparison: sees self as probably homosexual; feelings of social isolation

III. Identity Tolerance: sees self as homosexual; seeks out gay community

IV. Identity Acceptance: homosexual identity is accepted; more frequent contact with homosexual community for validation

V. Identity Pride: sense of anger at societal intolerance; devalue heterosexual others 
VI. Identity Synthesis: increases contact with heterosexual others; integrates homosexual identity with all aspects of self

Another model of development used in this research is Kus' (1988, pp. 2735) coming-out process for the gay individual. There are four stages:

I. Identification: the individual recognizes a gay identity; feelings of differentness are now explained

II. Cognitive Changes: sees being gay as a negative state of being, trying to rid self of homophobia by learning about the gay world, usually while passing as heterosexual

III. Acceptance: sees gay identity as a positive aspect of self

IV. Action: characterized by behavior based on acceptance of gayness as positive

This research reports feelings, ideas, experiences, and concerns as directly reported by gay and lesbian students. The format of the research includes confidential, tape-recorded interviews which includes open-ended questions and unlimited responses. The interviews were more like conversations and less like a traditional question-and-answer format. Each student had two conversations with the researcher: 1. an initial open-ended discussion preceded by an agreement to the terms of a regulation consent form and 2. a follow-up conversation with more limited and specific questions 
consistent for all participants. Each participant contributed at least two and onehalf hours of data.

The researcher interviewed self-identified gay and lesbian students. Students were given an opportunity to express themselves and the concerns of many gays and lesbians. This created an atmosphere of an unfolding, in many cases, of many years of stories and experiences reported for the first time. Most of their thoughts and meanings are typically protected in their individual, safer lives. Here they spoke of things with a sense of excited sharing and expressed gratitude at the opportunity to tell their story for the benefit of others without the burden of recognition.

The researcher initiated this study wondering if there was a better way to understand the developmental issues of gay identity for each gay and lesbian student. This was attempted by listening to the students' stories, identifying commonalties of their experiences and, finally, establishing relations with the models. Because this study was completely exploratory, there were no hypotheses for the analyses.

In this study, the information gathered in the interviews is described and related to existing theories of gay identity development. This study was undertaken to present some experiences, thoughts, feelings, and concerns of gay and lesbian students. This was used as a means to illuminate information which, when related to existing theories of gay identity development, may create more insight into the needs of this sub-population on a college campus. Toward this end, the literature review and findings were used to identify implications and recommendations for using the information, if a campus so chooses.

Further exploration of all of these issues requires definitions of some of the terms. For the purposes of this research a "gay" person is a male who relates 
sexually and/or intimately with another male and a "lesbian" is a female who relates sexually and/or intimately with another female. The word "gay" is also used in various forms to refer to gay and lesbian persons as a group. "Comingout" is the general term used to describe the action or process through which gays or lesbians reveal their sexual orientation. "Homosexual" means relating to or exhibiting sexual desire toward another person of same gender. 


\section{Chapter Two: Literature Review}

\section{Overview}

Similar to all people, several challenges await gays and lesbians as they grow and self-identify. According to Fairchild and Hayward (1989), direct heterosexual programming begins at birth. There are family and societal expectations, cultural norms, developmental milestones, and personal dilemmas associated with this presumption of heterosexuality. For most people, assuming a heterosexual identity and role has been seen as the primary task in preparation for much of adulthood, while homosexuality has been considered either deviant or ignored altogether. From early on, being gay is associated with going against the family at a time when much of our identity becomes rooted in family expectations (Berzon, 1979). These expectations are built into hopes and dreams for individuals.

Young gay people may experience an initial turmoil to the internalized expectations from family training. According to Isensee (1991), adolescence can be an especially treacherous time for gay youths: "Peer support, young people's major ally during this transition, is only minimally available to gay youths" (p. 19). This lack of support in an environment of extreme invalidation may have disastrous results. According to a study commissioned by the Department of Health and Human Services, gay youth are two to three times more likely to attempt suicide than heterosexual youth, and up to $30 \%$ of teens who do commit suicide are gay or lesbian (Maguen, 1991).

So what makes a person gay given that these conditions exist in their environment? The answer is still not available, but many researchers have put forth ideas and none have been conclusively validated. Research has discounted the theory that gays have dominant mothers and distant fathers. 
Studies have also concluded, as Isensee stated in 1991, that "More research is needed before we can say that a higher percentage of gay men have been sexually abused" (p. 56). Many persons continue to see homosexuality as a negative outcome of development stemming from either a homosexual role model or inadequate heterosexual role model identification (Riddle, 1978). Regardless of research, Fairchild and Hayward (1989) state that the "majority of gays with whom we talk either tell us that they think they were 'born that way' or the subject of causation is irrelevant for them" (p. 91).

\section{Sexual Orientation}

The first researchers on sexual orientation (Kinsey, Pomeroy, and Martin; 1948 \&1953) developed a scale of overt sexual experience. Results suggested that approximately $10 \%$ of the population (and probably more men than women) had an orientation toward predominantly homosexual arousal and experiences. There are no current reliable data which may, more accurately, describe the percentage of the current population which are gay or lesbian.

According to Fairchild and Hayward (1989), there have not been any definitive studies of how sexual orientation develops; they feel it is probable that none of us is born with a fixed sexual orientation. Shively \& DeCecco (1977) state that sexual orientation can be viewed as having two aspects: physical preference (individual preference for male/female sexual partners) and affectional preference (individual preference of male/female emotional partners). While according to Berzon (1979), sexual orientation is a moving, changing process, the development of sexual orientation probably parallels, but is not synchronous with, the development of social sex-roles (Shively \& DeCecco, 1977). 
Gender, sexual orientation, and social sex roles are important components in sexual identity formation. According to Larson (1981) sexual identity "can be conceived of as the set of self-referential attitudes, thoughts, and feelings about sexuality that, taken together, is a subset of the overall self concept" (p. 15).

\section{Homophobia}

For the person whose sexual orientation is gay or lesbian, the challenges faced are met head on with oppression and prejudice. Fairchild and Hayward (1989) believe that gay people can experience "a lifetime of persecution and self-denial" (p. 72). Homosexuality has been considered a sin, laws have made homosexual acts illegal, and until recently, homosexuality was treated as a mental illness (George \& Behrendt, 1987).

Oppression is perpetuated by more than individual people; oppression is a societal institution. According to Isensee (1991, p. 10)) individual prejudice toward gays and lesbians can be influenced by the following four things:

1. ignorance and lack of experience with gay people

2. conflicts with other beliefs and values

3. conformity and social norms

4. denial and projection of internal conflicts

The fourth influence is explained as follows. There are people whose prejudice serves a psychological function in their personality. For example, there are people who feel conflicted about their own homosexual feelings and desires. Others feel threatened by any challenge to traditional masculine/feminine roles. These people may experience internal conflicts about these feelings and project, or externalize them onto others.

When prejudice is supported by major institutions in society, it becomes a norm (Isensee, 1991). For example, gays are seen as disruptive to the military, 
in many states sex between men is illegal, and gay relationships, for the most part, are not legally recognized. "A nation whose social order remains patriarchal desperately attempts to recount and redefine its authority along traditional lines with an emphasis on heterosexual male authority" (Comstock, 1991, p. 136).

There is a term used to describe the phenomena of oppression: homophobia. Isensee's (1991) definition of homophobia is "the expression of prejudice against homosexuality in general, and toward gay people in particular" (p. 10). He also defines the concept of heterosexism as "heterosexual bias that institutionalizes heterosexual norms and discriminates against gay people" (Isensee, 1991, p.10) Both may be expressed via individual prejudice, institutional discrimination, and internalized homophobia.

Homophobia is reflected in many institutions: churches, schools, sports, the media, courts, and the military (Isensee, 1991). "Homophobia is manifested at the institutional level at colleges and universities by the invisibility and denial of the issues and concerns of lesbian and gay students, faculty, and staff" (Obear, 1990). According to McNeill (1988) the churches' traditional position about homosexuality has been " that since every homosexual act is sinful and contrary to God's plan, the love that exists between gay and lesbian people is sinful and alienates the lovers from God" ( $p$. xvii).

Homophobia is often described as an irrational fear of homosexuality. Fear of homosexuality is most strongly correlated with a commitment to traditional sex roles (Riddle, 1978). Homophobia is used as a technique of social control by individuals to enforce the norms of sex-role behavior (Hansen, 1982). It contributes to maintaining traditional sexual differentiation.

For almost every gay person, homophobic oppression is mentally and emotionally processed, thus becoming internalized. The process of 
internalizing homophobia requires four components: prejudice, misinformation, isolation, and heterosexual bias (Isensee, 1991). Isensee (1991, p. 14) defines these components as follows:

"Prejudice and systematic oppression make it extremely difficult to feel good about one's sexuality while growing up. This creates an environment of secrecy and shame that interferes with normal adolescent development and formation of positive gay identity. Then there is misinformation that homosexuality is sinful or sick. Because of a lack of knowledge, it is easy to assume that something is wrong when one first becomes aware of same-sex attractions. Members of groups that are discriminated against seek others in the community for solace, identity, and support. Gays are often cut off from any source of nurturing, recognition, or acceptance. Heterosexual bias promotes discussions about family policies that ignore gay and lesbian families, while the special needs of older or disabled gays are ignored."

\section{Self-definition and Identity}

Berzon (1979) writes "It is often easier to be defined by what other people expect of you, to merge into a stereotype, to yield individuality, to abdicate responsibility for being who you are and becoming what you want to be. Forever, it seems, gay people have been giving their power away to others: define me, explain me, etc." (p. 1). McNaught (1988) asserts that "Some homosexuals end up feeling trapped between their inner selves which are gay and the exterior world which continually rewards them for not being gay" (p. 19). Most homosexuals grow up hearing labels such as "faggot", "queer", and 
"dyke", and, therefore cannot escape incorporating the negative messages into their own self-concept (George \& Behrendt 1987).

The labeling issue is an important one with regard to the formation of a positive gay identity. Attaching a label to oneself tends to bring that aspect being labeled into one's consciousness (Berzon, 1979). Reiter (1989) states that if there could be an atmosphere of uncritical acceptance of a gay person's sexuality, the gay identity would become more integrated into the overall sense of self. Working through internalized homophobia often will allow the person to integrate a positive gay identity.

According to Berzon (1979), for gays, deprogramming internalized homophobic messages is a long and arduous process. She says, "We are all exposed to antigay jokes, stereotypes, and misinformation... We have swallowed all this toxic material" (p. 3). Hanley-Hackenbruck (1989, p.22) states:

"Initially, feelings of shame, guilt, doubt, confusion, and alienation result in what has been called a 'reality shock.' The shock occurs when the person suddenly discovers or finally admits belonging to the stigmatized group, but he or she cannot believe that the negative stereotypes could possibly apply to herself or himself. In developmental terms, an identity crisis is precipitated. The lesbian or gay must take this knowledge of 'differentness', integrate it into the current self-concept which stimulates individuation, both by incorporating a previously unaccepted part of the self and by overcoming the antihomosexual attitudes incorporated since childhood and current everyday life. Then the individual must find her or his own place within an unknown and foreign subculture." 
Berzon (1979, p.2) writes "Many gay people have been inspired to seek a better life through increasing self-definition and self-determination." Yet, according to Troiden and Goode (1980), gay identity is not embraced immediately, but rather is "acquired in a step-by-step fashion over an extended period of time" (p. 385). Part of embracing gay identity is acknowledging it to other people or "coming out."

\section{Embracing Gay Identity and Coming Out}

McNaught states that "the first important step toward self (coming out) takes you out of the clutches of the world and its expectations" (p. 20). According to George and Behrendt (1987), coming out is often the "first acknowledgement of self as homosexual and is usually very traumatic, especially if (one has) not challenged some of societal attitudes" (p. 81).

Hanley-Hackenbruck (1989) write that coming out involves a complex process of "intra- and inter-personal transformations often beginning in adolescence and extending well into adulthood which lead to, accompany, and follow events associated with acknowledgement of one's sexual orientation" ( $p$. 21). There are variables which significantly influence this process: gender, race or ethnic group, urban versus rural residence, values and attitudes of society at the specific time, and individual variation (Hanley-Hackenbruck, 1989).

Coming out may happen at any time in a gay person's life. According to Troiden and Goode (1980) those individuals who took a number of years to acknowledge their homosexuality may have needed to ready themselves emotionally before incorporating feelings and behaviors previously viewed as negative into their definitions of self. Gay and lesbian youth of today, however, are coming out sooner but suffer from a higher degree of intolerance because of the expected backlash to the gay civil rights movement (McNaught, 1988). 
A number of clinicians and researchers over the past decade or so have developed models of the coming out process. They all describe the common elements observed in various gay and lesbian populations and incorporate the tasks of emerging awareness leading to expression and disclosure of their sexual orientation. Each model attempts to integrate the complex interaction of personal and societal factors while emphasizing specific milestone events (Hanley-Hackenbruck, 1989). The following is a summary of three of these models as it appeared in Hanley-Hackenbruck (1989, p. 24):

Iheorist (Year)

Stage One

Stage one

Grace (1979)

Emergence

Coleman (1982)

Preconscious

awareness

Stage Two

Acknowledgment

Stage Three

Crashing out

Stage Four
McDonald (1982)

Awareness
First relationships

Self-definition

\& Reintegration
Coming out

(Acknowledgment)

Understand word:

"homosexual"

Exploration Self-labeling

Exploration Self-labeling

First gay experience

\author{
"homosexual
}

First relationship

Integration

First relationship

First disclosure

to non-gay

Positive gay identity

When gays and lesbians acknowledge and disclose their identities, they often tell those people with whom they have the most personal history and investment: their family. What do people hope to receive from their family?: love, support, validation for accomplishments, comfort, and attention to their 
struggles with life's dilemmas (Berzon, 1979). Gay persons risk all of these in coming out, particularly from their parent(s). Elaborate defenses gays establish to protect themselves are often reinforced when they come out and lose their family (McNaught, 1988).

According to Fairchild and Hayward (1989), for parents, often the worst part of learning of their child's homosexuality is the questions: "Where did we go wrong? How much of this did we bring on ourselves?" (p. 6). Some parents try to project their burden of trying to figure out where they went wrong in their parenting that caused the homosexuality by transferring it to the child: "How could you do this to us?" Some parents cast around for outside influences. One of the most difficult problems confronting some parents in accepting their children's homosexuality is from their religious beliefs; churches constantly call homosexuality a sin (Fairchild \& Hayward, 1989).

\section{Development Theories}

The following section provides more information about the two models (Cass, 1979 and Kus, 1988) which are a focus of this project. However, to lend support to the use of these models, the researcher has included a review of Erikson's (1968) psychosocial developmental theory as presented by Evans and Wall (1991). Erikson's theory is acclaimed and recognized in discussions of development, but as will be further noted, he assumes heterosexuality in adolescents. While his theory provides an adequate framework to understand ego-identity, Cass (1979) and Kus (1988) are relied upon, for this research, when considering development of gays and lesbians.

According to Evans and Wall (1991), Erikson's (1968) work included a psychosocial view of developmental tasks, with a focus on development within a social context. His theory emphasizes interactions with parents, family, social 
institutions and culture all bounded by a particular period in history. The theory states that developmental tasks are experienced by individuals during each of the proposed developmental stages. These tasks occur when physical growth, cognitive maturation, and certain social demands converge. Each stage poses a dilemma with a unique set of issues; eventually, he suggests, there will be a crisis point when decisions must be made about the dilemmas. Successfully overcoming these dilemmas allows one to move on to the next stage toward a sense of identity.

Erikson's (1968) eight stages of development extend from early childhood to late adulthood. According to Erikson (1968), the central task of young adulthood is the development of identity. He considered the role of the environment in identity formation and the meaning of ego-identity: "Who am I?" and "What will I be?" The tasks in this stage include the integration of adult sexuality into one's personality. According to Evans \& Wall (1991, p. 26), "no mention is made of the possibility that one's emerging sexual identity might be nonheterosexual or of the difficulties of conforming to the societal norms if one is gay or lesbian."

In Kus' (1988) theory, he proposed four stages ranging from "Identification" to "Action." In stage I, "Identification," a gay person recognizes their gay identity and begins to understand feelings of differentness. Internalized homophobia result in feelings of "guilt, low self-esteem, shame, depression symptoms, and so on." (Kus, 1988, p. 27)

In stage II, "Cognitive Changes," a gay person tries to learn about the gay world while passing as heterosexual. This happens in effort to let go of the internalized homophobia, even though the gay person may still see being gay as negative. During this stage, the gay person is fearful of being discovered as gay and expends tremendous effort to pass as heterosexual. 
The third stage, "Acceptance," sees the gay person accepting their gay identity as positive, thus free of the negative feelings of the first two stages. This moves into the fourth stage: "Action." This stage involves behaviors which indicate an acceptance of gayness as a positive aspect of self. In this stage, typical behaviors include "self-disclosure, participation in gay political activity, changing friendships to include more gays, and the like" (Kus, 1988, p. 35).

Cass' (1979) theory provides an account of the identity formation process for gay or lesbian individuals. She proposed a six-stage model in which the person has an active role in the acquisition of a homosexual identity which is integrated into the overall self-concept. In the first stage, "Identity Confusion," the process begins when a person begins to think their feelings, thoughts, or behaviors can be defined as homosexual. This realization presents incongruency in a previously stable situation. A person is at odds with an earlier view of self as heterosexual and begins to experience doubts. By the end of the stage, the person begins to accept the possibility that their identity may be homosexual.

At the beginning of the second stage, "Identity Comparison," the confusion from the first stage is reduced. At this point, the person has begun to resolve "Who am I?" and is beginning to have feelings of social isolation and of not belonging The individual begins to realize their previous heterosexual guidelines for behaviors are no longer relevant.

At the third stage, "Identity Tolerance," the individual sees that "contacting homosexuals is something that has to be done in order to counter the isolation felt and alienation form others" (Cass, 1979, p.229). The individual tolerates, but does not accept a gay identity. While making contact with the gay community becomes important, the quality of the contact becomes most 
important; unrewarding contacts may result in a devaluation of the gay community.

A continued and increasing amount of contact with other gays and lesbians characterizes the fourth stage of "Identity Acceptance." The person now accepts instead of tolerating a gay self-image. For the gay individual, "inner tension is felt. Until now, considerable weight has been given to others outside the gay community, and to their nonlegitimatizing policy" (Cass, 1979, p.232). The difference between how the person perceives themself and how others perceive them is accentuated. This lead to the next stage.

Cass' (1979) stage five, "Identity Pride," finds the gay individual managing the difference between their self-perception and that of others by devaluing heterosexuality and positively valuing homosexuality. Commitment to the gay community becomes very strong, thus creating a sense of pride. The individual becomes far less concerned with how non-gays perceive him or her and is more likely to disclose their gayness or "come out."

The final stage, "Identity Synthesis," occurs when the individual decides that the simple and dualistic division of homosexuality and heterosexuality no longer holds true. The individual acknowledges that there are some heterosexual others who accept their gayness. The individual is now able to integrate their gay identity with all other aspects of self. These developmental theories of gay and lesbian identity development can significantly enhance the understanding of gay and lesbian student challenges.

The purpose of this research is to present experiences, thoughts, feelings, and concerns of gay and lesbian students and relate these to existing theories of gay identity development. This research will give meaning to the implications of the findings and make recommendations for programming on college campuses. 


\section{Chapter Three: Methodology}

This research utilized a qualitative approach to collecting data and analyzing findings. Patton (1990) writes "Qualitative methods typically produce a wealth of detailed information about a much smaller number of people and cases. This increases understanding of the cases and situations studied ..." (p. 15) Qualitative methodology allows a researcher to study issues in depth and detail. Patton (1990) also writes:

"The purpose of qualitative inquiry is to produce findings. The process of data collection is not an end in itself. The culminating activities of qualitative inquiry are analysis, interpretation, and presentation of findings. The challenge is to make sense of massive amounts of data, reduce the volume of information, identify significant patterns, and construct a framework for communicating the essence of what the data reveal" (p. 371).

This approach allowed for gathering the maximum data in a controlled environment for the particular focus of this study.

Although there was no hypotheses, the researcher was guided by different questions: What were the students thinking about? What have been their experiences on their campus? How would the existing theories and models relate with the students responses? How is the development of the students' gay identities impacted by their challenges?

The researcher contacted an officially recognized gay and lesbian student group in order to make contact with students who would be interested in participating in the study. The researcher attended one of the group's meetings, announced the study, and left further instructions about being contacted. Some students immediately responded; in other cases, students from the organization 
referred other gay and lesbian students (who were not affiliated with the group) to the researcher.

The sample of students for this research consisted of eight full-time, undergraduate students from a middle-size, public university. They ranged in age between 19 and 23 years and in academic year between second and fourth years. One of the students lived with their parents, two with relatives, and five in houses with other students. The academic majors included education, German, human development, medical technology, psychology, and pharmacy. Three of the students were male and five were female. Three students had no siblings and the rest had two or three. None of the students had disabilities apparent to the researcher. Each student appeared to be of Caucasian origin and all of the students' parents were still married except for one case of divorce.

Because of the means used to gather the students, the sample is not random and has limitations. It may be appropriate to conclude that this particular sample of students is not in the beginning of their coming out process or identity affirming stages. It seems doubtful that this sample would include students who are in the pre-awareness stage of their gay identity, because those students would be less likely to participate in a study such as this which requires that the participants recognize themselves as gay. A bias in the sample resulted from some of the students being involved in the organized student group; this presupposes that the students are at an advanced level of recognition of their gayness.

Once interested, the students contacted the researcher who, in turn, reiterated to the student the purpose of the study and the means of gathering information. Once the student agreed to participate, the researcher set up an appointment with the student for a confidential and tape-recorded interview session. 
This research was conducted in two different phases: initial in-depth, openended interviews and follow-up interviews. The interviews took place in a quiet and discrete room on campus. During all interviews, a tape recorder remained on a table between the student and the interviewer.

At the onset of the initial interview, the researcher discussed the consent form with the student and they both signed it. (See Appendix A). The consent form explains the purpose of the study, the rights of the student participants, and any relevant procedural information. Along with the consent form, the students were given a resource sheet which listed people and places for resources for gays and lesbians at the campus as well as near the campus. (See Appendix B).

The interviews began by the researcher making the following statement: "Tell me about yourself." As the student responded, the researcher generally asked the student to expand on statements and points as they came into the conversation. If it seemed that students were discussing a particular issue at the surface level, the researcher asked the student to expand. In other words, if the interviewer sensed that the student could add more information or thoughts to what they were saying, the interviewer asked them to do so. This request was not related to or limited to any specific topic.

The researcher took notes during the interviews. In some interviews, the researcher and the student took a break during the session; this was dependent upon the student's request. In all cases, the initial interview was conducted on one day with the interruption of a small break only. The initial interviews averaged two and one-half hours in length.

Patton (1990) states that "The purpose of open-ended interviewing is... to access the perspective of the person being interviewed. We interview people to find out from them those things we cannot directly observe" (p. 278). The researcher listened to each tape from the initial interview several times and 
transcribed them. (The researcher was the only person who listened to the tapes). Once all of the scripts were completed, themes and commonalties were observed and recorded. This provided the means by which to report the findings. These scripts were also the basis for the follow-up questions.

The questions posed in the follow-up interviews were determined by the researcher based on the results of the first interviews. (See Appendix C). The questions were original to this study. These questions were necessary to clarify statements made during the initial interviews. All of the students were asked the same follow-up questions in confidential, tape-recorded sessions similar to the initial interviews.

One limitation of this methodology is in the generalizability or reliability of the findings. Given that the sample was small and not random, it may be difficult to apply the findings to a broader sample of the population. It is important to note that this research focuses on a small representation of a larger population. This study has allowed for a concentrated examination of a very specific sample. The intent of this study was not to be generalizable, but to observe and analyze a specific set of students at a specific time on a specific university campus.

The researcher entered into, implemented, and completed this project with a background which had its own impact. The researcher brought experience as a counselor, learnings specific to a graduate level human development student, knowledge about current gay and lesbian activism and pertinent issues, personal experience in many of the stories shared by the students, and a high level of campus visibility among the gay and lesbian student population. These characteristics may have affected the interactions with the students, the interpretation of the data, and the perspective of the researcher throughout.

Given that the researcher has learned counseling techniques, listening and probing skills were effective. Knowledge about gay identity development was 
utilized in interpreting and reacting to the data. The researcher's personal experience with many of the relevant issues may have enhanced the ability to identify themes as well as the ability to speculate when the student could expand their thoughts. 


\section{Chapter Four: Results/Findings}

As the interviews were analyzed, statements made by the students fell into several different themes. The themes emerged naturally as the researcher listened to the tapes; the follow-up interviews clarified the existing data in each theme. This chapter will summarize those themes and include the quotes of the students as they relate to the themes. The themes are sectioned alphabetically as follows: campus climate, career concerns, classroom experiences, coming out experiences, fathers and mothers, first gay experiences, gay men about gay men, thoughts on being "out of the closet," other-acceptance, parents, reasons for being gay, religion, and self-acceptance. The researcher's analysis of developmental implications to the findings appear in chapter five.

There are two different symbols used throughout the quotations:

1. "XXX" indicates a substitution for a name which must be omitted to ensure confidentiality.

2. GLBA is an abbreviation for the "Gay, Lesbian, and Bisexual Association," the undergraduate student group whose members make up some of this study's sample.

\section{Campus Climate}

The first theme focuses on the campus climate. The statements reflect the experiences of the students at the common university atmosphere they all share as members now. The statements reflect feelings and experiences about the campus and campus life in general.

-We have had threatening messages on the answering machine at the GLBA office. There was police protection at the next meeting. 
-In my first year I never spent time in my dorm except to sleep... The first year was awful.... Everyone acted so straight.

- It's frustrating on campus because approximately $10 \%$ of the population is gay...Where are they?!

- I went home every night and weekend to get away from campus.

- I don't think the GLBA will get widely recognized; there would be a lot of problems.

-Sometimes I feel like I should hide my pink triangle button because I get scary pangs.

-I would like to be able to walk on campus holding hands without fraternity guys jumping out at me.

-Some people saw me at a party with other gay people and I was afraid to go back to class.

-When I see a poster or something on campus with anything about gay stuff sometimes I expect someone to start screaming obscenities about it. But I think people are starting to realize there are gay people on campus.

-I would like for gay issues to be talked about more, because many people are basically unaware. 
- In my first year I hated my roommates. They were so feminine and used all this hair spray... and all they talked about were the boys down the hall.

-I went to a discussion for a movie about Harvey Milk and there were professors there who were openly gay. I was shocked that they were there... Seeing professors that are gay, that can speak up, made me feel really good. I couldn't say anything, but I was cheering them on inside.

- I worry that if a lot of professors came out, students would be afraid to talk to them.

-For the GLBA I would like full support of the faculty and administration and support of other groups. Not that we need to justify our actions, we'd just like support.... We'd like simple acceptance of who we are and what we do.

-I would like to see housing rights for all graduate students' partners and faculty partners. I would see it as a statement of "You're okay just like everybody else."

The students described incidents of harassment, feelings about fear of being harmed, feelings of isolation from other students, frustration about little visibility of other gay students, leaving their residence hall as a means of escape, and a lack of support from the campus community. Although there was much discussion about negative feelings, the students also said some positive thoughts. They expressed that they felt that the campus was beginning to 
recognize the existence of gay and lesbian students and faculty and that seeing openly gay and lesbian faculty was encouraging.

\section{Career Concerns}

In their expressions of concerns about their careers the students discussed different types of potential career decisions, how out they want to be in their careers, and uncertainty about the environment of their impending career.

- I am not sure that I want to work in my major because of being gay in that career.

- I am not sure if I should put my experience with the GLBA on my resume...I should have the right to put it on my resume.

-This [whether or not to be out in a career] is all a big, black cloud looming over my head.

-I want to be a counselor for adolescents who are struggling with their sexual identity. I can understand what they go through with their parents. I want to be out in my career.

-I don't want to graduate. I want to hide as long as possible on campus.

- My field is mostly all men and is not gay affirmative. I have had some worries about being out to my co-workers. 
-(lesbian's statement) It's tough at work because everybody is talking about what they did with their husbands over the weekend and I can't say anything.

-Right now, I am not sure how gay issues are accepted in my profession, so I am not going to tell anyone.

Here, there was much discussion about the students not being familiar with the type of acceptance of the gay lifestyle in their different careers fields. They expressed apprehension about including gay co-curricular activities on their resume and about being open about their gayness to colleagues, while, in most cases, the students would ideally like to pursue gay issues in their job worlds.

\section{Classroom Experiences}

Many vivid stories of what has happened in the college classroom were related during the interviews. Some stories talked about the professors' behaviors, some about the other students, and others about their own feelings of being a member of the class.

- In my sociology class the professor talked about gays as a subculture and I found myself not wanting to talk about it in class... It was presented well.

-I haven't heard many direct homophobic comments in class, but there are never any positive comments.

-Nobody mentions gay authors in English courses... That can destroy the literature because you miss what they were trying to say. 
-In class people around you say gay is gross... and the professor doesn't say anything to them.

- I dropped one of my classes when the professor classified gays with farm animals at the suggestion of students and then she just smiled and laughed.

-The males in the class practically went to the remote corners of the room (during the student's discussion on being gay).

- Teachers need to give the real story about being gay. I hate myself for not saying something, but right now I can't because there is always someone in the class who knows someone I know.

-No one seems to be concerned about gay issues... The only exposure l've gotten is in a discussion about AIDS.

Students expressed discomfort about speaking out in class about gay issues and frustration about feeling limited about class discussions about gay issues. In some cases, they felt that the professors avoid the topic, and in other cases the students themselves avoid it. A couple of students conveyed homophobic incidents on the part of the instructors.

\section{"Coming Out" Experiences}

Discussing the coming out experiences was one of the more frequent themes in all of the interviews. The students shared stories of coming out to 
their family, coming out to friends, and issues concerning the decision to come out.

-I came out to my family about a year ago... I took a deep breath and told them.

-...[Coming out] is very important in a gay person's life.

- Not everyone should come out to everyone else.

- I came out to my family because I want them to know me as intimately as possible as their gay son.

-I haven't come out to my extended family.... if that is the only aspect which would upset them about me then I won't tell them.

- Coming out is a private decision; it can't be forced.

-I tried coming out to my parents once, but it didn't go well... Now I am back where I started... When I'm ready I'll try again.... probably after graduation when they can't do anything to me like take things away like they did before.

-Friends that I waited to come out to asked why it took so long... I tell them it was because I was afraid to lose them the way l'd lost others.

-When I came out in class it was like take me or leave me... They had to face it right away. 
-When I was 18 and told my parents I was gay, they pulled me out of school.

- I came out in a small class and then said I thought it was a mistake [to be gay]... because I regretted telling them.

- I had a lot of trouble coming out and saying it directly. I didn't say I was a lesbian, I just said I was dating a woman.

The students related two main observations about coming out: a sense of caution about coming out and the importance and individuality of the process. They said they hoped that coming out would result in a closer relationship with others, while they expressed fear of losing family and friends after coming out to them. Some of the students also mentioned parental and peer reactions to coming out and the repercussions involved.

\section{Fathers and Mothers}

Within the natural flow of the conversations, the students would often speak of issues with their parents, especially in terms of coming out. As they shared their stories, however, there were typically specific comments made about their fathers and specific comments about their mothers. (Again, with one exception of divorce, all of the students' birth parents were married at the time of the interviews.)

This section reports direct statements about the students' fathers. The students talked about their fathers' feelings about their child's gayness, about when they came out to him, and some about their current relationship with him. 
- My only conversation with my father about this [my gayness] is about health concerns.

- My father was as shocked as you can get and it took him a while to come to grips with it.

-My father is a silent person... He just grunts.

-When I told my father he said his love would never change, but he was unhappy about it.

- He was concerned for my future and happiness... He just didn't understand.

- My father was afraid I would contract AIDS.

- My father was concerned about the effects on my career.

- My father never talks about this.

-He didn't take it well when I came out... He used to show pictures of me to the guys at work and talk about what a good wife l'd make.

-The women at my mother's gatherings used to say how much they loved me and I couldn't imagine my father saying that.

- I didn't come out to my father directly. We don't have real good communication between each other. I told my step-mother and she told him. 
He was kind of hurt that I didn't tell him directly. I am still not real comfortable talking to him.

-When I came out, my father just sat there... He didn't say anything. He didn't have an opinion.

-My father just kind of went along with my mother.

The following are quotations of comments about the students' mothers. The students talked about their mothers' reactions to them being gay, their mothers' concerns, and some of their behaviors.

- My mother and I had a heated discussion about me being gay.

-She is concerned about places I have to go to meet people... "downtown."

-She makes comments like "Look at those fags on TV."

- My mother talks about me being gay. We have become very close.

-Mothers always know when their child is gay. My mother said she knew from. day one.

-My mother cried when I came out to her.

-At first my mother had problems with it because she already had one daughter who had come out. She really didn't believe me, she thought it was my 
sister's influence on me. She had [previously] asked me if I was gay and I said no. I didn't want to hurt her. So she was hurt that I had lied about it... I was her pride and joy.

-I had always had boytriends, so she had this totally positive image about me... that I was going to get married, she'd have grandchildren. And then all of a sudden I changed. She couldn't understand why I didn't want to be with a man anymore.

- My mother is picky about who I date. There's been a few people I've been with that she hasn't liked.

When students discussed their fathers there were strong and consistent sentiments about an absence of conversations about their gayness with their fathers and about generally not communicating with their fathers. Statements about mothers often focused on the emotions expressed by the mothers. There was a sense of fragility about their mothers the students expressed as well as feeling what they perceive to be protectiveness from the mothers. Many of the students had more expectations of emotional support from their mothers.

\section{First Experiences}

The students reported what they described as their first experiences of being gay. In some cases it was when they first became aware and, in others, it was an event in their life. (The researcher chose to separate "first experiences" from "first relationships" [the next section] because of the different implications they each have. "First experiences" were those which the students discussed 
when reflecting on the first indications of their gayness, as opposed to their actual "first relationships".)

- I always knew I was different... I didn't understand my attractions to other boys.

-I started to come to terms with my gayness in about my junior year in high school.

-I had my first gay sexual experience when I was 19.

- I always liked blowing kisses to other girls when I was little. I liked short hair, no dresses, and always wanted to play sports with the boys.

-(lesbian's statement) I have always looked at other women. I was never attracted to guys.

- I considered suicide when I was a teenager because things were so hard.

- I first associated myself as a lesbian after I broke up with my first girlfriend... I was in my second year of college. Until then I didn't really know what the term lesbian meant.

-When I first started thinking other women were attractive, I used to tell myself I only thought that because I wanted to look like that.

-I was exposed to gay people when I was growing up and I used to hear negative comments about it. I never thought of it as an option. Then when I 
became gay, I used to think it was awful, that people were going to hate me, and that a lot of bad things were going to happen to me.

-When my older sister came out, my first curiosity about being gay came up. I guess I was pretty ignorant until then... I asked her questions about her life, but I did not apply anything to me... I didn't know about me.

-When I was a little girl, I always had crushes on my female teachers... even since kindergarten.

The students discussed that they did not understand their first experiences when they happened and, in some cases, wanted to deny their homosexual feelings at that time. They also sought means to rationalize the experiences.

\section{First Relationships}

As the students talked about their life's history, they often recalled what they defined as their first gay relationships.

-In my first relationship with a gay man, I shook so much... uncontrollably. I was just out of high school.

-I wasn't comfortable.

- I became involved with my high school teacher.

- It was incredible and terribly romantic. 
-We were friends for one year before the relationship. The physical progression was very natural.

- I didn't think much of it except that it was weird.

-We stayed together because we didn't have anyone else. It was sometimes abusive, but I needed that link with someone. It was really hard.

-I used to get sick to my stomach because I wasn't sure.

-We were friends for about the first year. It was a strange, tense relationship. All of sudden we just decided we were attracted to each other. It was a lot of fun; it was something very new.

-There was this girl that I had been friends with from another town... during the summer after my junior year in high school... She had always made me tense, I don't know why... We became involved.

These relationships, which were identified by the students as their first gay relationships, were described in many ways: from scary to wonderful. Many students talked about friendships which naturally progressed to intimate, sexual relationships. In most interviews, the students talked about not being comfortable during the time of their first relationship.

\section{Gay men about gay men}

The gay men interviewed made very distinct references to gay men in general. The references were made in connection with no other specific topics 
of discussion. Sometimes there was a comparison of either gay men to each other or gay men to ron-gay men.

-I don't think gay men are into relationships.

-They are all looking for the perfect thing... physical attractiveness and social establishment.

- Gay men are better friends than straight men because they are not bent on doing the macho thing.

-You can't trust gay guys... They move too quickly and are just interested in conquering.

-You have to date them for a long time to get them to really talk about themselves.

There was a sense of discomfort, perhaps even dislike, and negative judgements by the gay male students about gay males in general. This may be a result of the students internalizing traditional messages about gay men. It may also indicate discomfort about themselves.

\section{On being "out of the closet"}

The students also discussed their thoughts on being "out of the closet". The students focused primarily on their own decisions about how much of their lives they have chosen to share. Some discussed reasons for being out or the feelings around this issue. The statements made by the students are as follows: 
- I am not out to my athletic team or to my family, but I could tell my teachers.

- I am very out on campus... It feels good to be out.

-I know I won't always be able to be out.

- I believe in outing someone if they are politically active against gay rights and they are gay themselves.

-Our relationship grew apart because I wanted to be out more than "XXX" did.

-There are two other people on my team that I know are gay.... We would never stand in a group and talk.

-I want to be more out politically, but my safety is important.

- I'm out to people I live with... I'm sure a lot of people know.

-I don't feel it is necessary to tell my teammates because there are people who look up to me.

- I can't wait for the day I don't have to hide anymore.

-My friends used to ask me where I was going, when I would go out, and I would lie. 
-Sometimes I catch myself acting gay in front of my team and I will stop. I don't think they have caught me yet.

-It's difficult to know "XXX", in a way, because she is out... there are times when I would be around her and she would say something gay and my friends who don't know about me would hear it and I wasn't ready for them to know.... I didn't know how to react... I was uncomfortable about that.

There was a range of "outness" among the students which seemed to vary according to environment. There was concern about a "guilt by association" with other gays and lesbians; some of the students were concerned with being affiliated with other gay persons in particular environments because they feared being seen as gay themselves. The students saw being out as having risky and unsafe consequences in some cases. They also identified being out with losing relations with family members and/or friends.

\section{Other Acceptance}

Another theme which emerged is that of the acceptance, or lack thereof, of gayness by people other than the students themselves. This group includes friends, classmates, and the general public.

- If I wanted to fit in, I wouldn't do the least popular thing in society.

-(gay man's statement) My friends always asked me why I wasn't getting involved with women and I'd say I had a girlfriend back home... they'd question me because they hadn't met her... I did a pretty good job of blowing off what they said. 
-If people see me at (a gay function) they don't talk to me anymore... Those who have begun to again don't bring it up.

-I would like simple acceptance of who we are.

- It was amazing when my classmates discovered that gays and lesbians are not that much different from them and they softened their attitudes.

-Who knows what people say behind my back? But I don't care.

The students certainly gave thought to outsiders' perceptions of their gayness. There was a general sense that they do not feel accepted in their environment. They discussed hiding their gayness because of this nonaccepting feeling, while they expressed a lack of caring and investment in these outside attitudes. There seemed to be some incongruity between reported behaviors and internal feelings.

\section{Parents}

While a portion of students' comments were specific to either their mother or father, often the stories about parents addressed them as one unit. They talked about their current feelings toward their parents as well as feelings they have had in the past. They shared examples of parental reactions to their gay lifestyle, parents' ideas on reasons for and permanency of being gay, and a sense of indebtedness to their parents.

-My parents never say the word "gay." 
- My parents make sarcastic digs when they give me phone messages.

- My parents believe if I know they don't like me being gay, I won't like it either.

-They say, "You're just hanging around with a lot of gay people so you're just doing it to fit in."

-I felt like my parents wanted to find out more than I wanted to tell them... They wanted to hear me say the actual words: "I am gay."

- My parents still think I am heterosexual.

-I felt like I was using them to pay for school.

-I have to hide my typical behavior in front of my parents. I have to hide things in my house.

- I can't wait until I have my diploma and my own money; then they can't touch me anymore.

-As soon as my parents found out about me, the Bible was on the table.

Two important observations were derived from these statements: The students felt as if their parents have attempted to change their gayness or to convince them that they are not really gay. Also, the students often expressed 
feelings of guilt about using parental resources for themselves given parental disapproval about their lifestyle.

\section{Reasons for gayness}

Though the students did not focus much on the next theme, they each spent some time either pondering or hypothesizing the reasons they are gay. There was a variety of statements.

- I don't know if I was born this way.

-The openness of your environment influences if you'll act on it.

- (gay man's statement) Two things happened to me when I was little that has happened to almost every other person I know who says they are gay or confused: I was molested and I didn't spend a lot of time with my father.

-I wouldn't choose to be born this way... into a predominantly straight culture in America... l'd have to be crazy!

-I think about why I am gay every day.

-I did a lot of things with my mother that little boys shouldn't do... I went to meetings of all women and wanted to be one because they got along great with each other.

-It just comes naturally... I didn't wake up and choose this way. 
These comments seemed to range as much as the literature does in speculating why people are gay. In some cases, the students may have internalized misinformation. Just as the literature indicated, the students seemed to think this is not an important topic.

\section{Religion}

Religion was a strongly discussed theme. The students looked at religion in their daily living, as an institution, questioning generally accepted religious beliefs, and the impact on gays and lesbians.

-I have a big problem with organized, Western religion. They have fucked up people's lives for thousands of years.... especially the Catholic church. It is riddled with absurd beliefs.

-I wondered if I would fry in Hell because I am gay. I finally reconciled that when I interpreted the Bible carefully... Christ never mentioned homosexuality and he preached forgiveness. How could he be upset with people like us? Homosexuality is a normal aspect of human sexuality.

-This is who I am and I couldn't change it if I wanted to. How could God be upset with me?

-I am a member of a particular religion. They probably think I am the worst evil ever to walk on Earth.

- Organized religion is one of the biggest hoaxes in the human race... It is used to control people. 
-Homosexuals are not accepted because religion says they shouldn't be... for the most part.

-I don't believe anyone can be happy as a Catholic. Many of them go to church out of habit.

- One of my friends was in a two-year gay relationship. He went to church.... they grabbed him and now he doesn't even know who he is.

-I am not the most religious person... I am not interested in religion.

This topic seemed to tap strong emotions within the students. For the most part, the students reported to not be involved with organized religion. The students seemed angry at the traditional concept of religion and felt very unaccepted in it. There was a disbelief in its fundamental teachings and beliefs.

\section{Self-acceptance}

The final theme is self-acceptance on the part of the gay or lesbian student interviewed. These statements represent a great range of emotions and degrees of comfort.

-When I saw gay people on TV when I was young, I thought "I don't want to be like that."

-I am very happy and proud to be gay. 
- I came out to myself as gay instead of clinging to bisexuality to conform to societal expectations.

- There is nothing I can do about being gay.

-If I could change my gayness, I wouldn't.

-I had the worst self-concept in high school... I had really low self-esteem.

- I am happy to be a lesbian and to date women. I am very comfortable with this lifestyle. I tried dating men to be sure.

- I am very comfortable with my life and my lifestyle. That is probably the most important quality about me.

Some of the students expressed pride about their gayness, some were happy, and others expressed compromise. Many of the students, in their retrospections, were not accepting of themselves, but had become more accepting. For the most part, the students reported having positive selfacceptance.

The interviews brought to light many different themes. The students each heard the same opening question and each took off in their own direction, yet each spoke of common themes. The summary which follows will tie these themes with the literature and with the researcher's observations, and will discuss findings and conclusions. 


\section{Chapter Five: Summary}

This research has described and delineated the challenges faced by its sample of gay and lesbian undergraduate students. The purpose of this study was to relate its findings with existing theoretical models of gay identity development. The gay and lesbian students in the sample exemplify how their challenges and obstacles have impacted their gay identity or sense of self as gay.

The depth of some of the researcher's conclusions are not precisely substantiated by the findings as they were presented. The tones of the interviews impacted the researcher's observations. During the discussions with the students, the researcher observed confusion and low self-esteem about individual personal situations. Stories were related with expressions of sadness, frustration, anger, amazement, and helplessness. With few exceptions, the students seemed to be deeply impacted by their life experiences. There were some instances when the students seemed encouraged or content, but those instances were much less frequent.

The students had spent much of their adolescence in secrecy and fear; they did not have the opportunity to experience support and inclusion of their gayness. There was little, if any, recognition or integration of their gay identity into their totality. As a result, they came to college without fulfillment or recognition of the very basic needs critical to identity development: supportive peer and family relations, self-exploration, appropriate role modeling, and societal recognition.

Indeed, these students are faced with integrating a stigmatized identity into an environment which includes a continued absence of awareness and understanding from members of the campus community, including peers, staff, 
and faculty. They experience harassment, isolation, and minimal interaction with other gays and lesbians. There was no recognition that their gay identity was different from that of the typical heterosexual identity.

The challenge of typical developmental issues had been compounded by the lack of informed support in their environment. This can be summarized by suggesting that this specific campus environment is not supportive for these students and that the students ranged in different levels of development. Instead of entering their college years with a foundation of a strong sense of self, these students had experienced invalidation, harassment, and discouragement against being their true selves.

Following is a summary of the findings from the different themes in the data gathering. The students statements showed the isolation, harassment, secrecy, and difficulty in the coming out process for the students. Their stories were poignantly emotional and the students had a sense that there were penalties and consequences for sharing their gayness with others.

There were differentiated comments about mothers and fathers. As the literature (Berzon, 1979) pointed out, heterosexual programming begins at birth by families, thus creating identity expectations. The researcher wondered how much the relationship distance between the students and their fathers is due to the gay lifestyle and how much is the result of traditional father-child relations. Robinson (1982) found that two-thirds of gay men and women perceived their relationship with their father as satisfactory and over three-fourths perceived their relationship with their mother as satisfactory. It would be interesting to uncover how much the perceptions of these students about their mothers are accurate and how much are traditional expectations about mother-child relationships. That is, children are socialized to expect their mothers to be the 
primary providers of emotional sustenance and perceptions about mother-child interactions may include assumptions based on socialization patterns.

There was a significant amount of career concerns of the students. The students have a severe lack of information about the gay lifestyle in their particular career. When students are attempting to integrate their gay identity with all aspects of their life, they "may have many questions about occupations and the acceptance of gay and lesbian people in the working world. Information that is both general and specific to gay and lesbian career choices is helpful" (Hetherington, 1990, p.135)

Stories about classroom experiences were, in some cases, far more negative than the researcher might have speculated. The students' participation levels were affected in most of the classes because of these experiences. They either did not want to speak out about gay topics for fear of being identified as gay or because they did not feel they would be supported by the instructor or other students. This is indicative of Cass' (1979) fourth stage of acceptance with inner tension about others' perceptions. It seemed that the students were not fully integrated into the classroom experience; they expressed that they do not feel completely included. This may result in less interest and motivation in learning and further alienation from peers in the classroom.

There was some sense of optimism among the students about the acceptance and affirmation of the gay lifestyle in the future. This may have something to do with integrating a positive sense of self, as some of them have begun to do. This integration of a sense of a gay self as positive is described in Kus' (1988) third stage: the acceptance stage. The literature (Cass, 1979; Hanley-Hackenbruck, 1989; Kus, 1988) states that finding a positive self-identity begins with accepting a gay identity and then acknowledging it to others. 
Six of the students had recognized their gay feelings since childhood, but were not able to match them up with the rest of the world because of the presumption of heterosexuality. Two resources (Isensee, 1991; Maguen, 1991) indicated that for gays and lesbians, adolescence is a tumultuous experience because of internalized expectations and lack of support and that the suicide rates among gay teens are alarmingly high.

The researcher has much concern about the negative comments made by the gay men about other gay men. Given that gays and lesbians have many issues which negatively impact their self-esteem and self-identity, this type of presumed internalized homophobia can be particularly damaging. Three studies (Berzon, 1979; George \& Behrendt, 1987; Isensee, 1991) found that internalized homophobia results in negative feelings about one's self, thus an identity crisis may result. This may happen in the third stage of Cass' (1979) model: identity tolerance.

The researcher suggests that along with internalized homophobia, some of the student's statements are the result of traditional gender socialization. Men are socialized not to value interpersonal intimacy, communication, or emotions. It may be that these gay male students have accepted traditional gender stereotypes and are perceiving them in other gay men.

For the most part there was a sense of defensiveness when the students were exploring why they are gay. As Fairchild and Hayward (1989) stated, the origin of and reason for gayness in individuals are still unknown and to most gays and lesbians it is not important. The students seem to experience an intrapersonal struggle in this issue: Is this my preference or my sexual orientation? They seemed to feel that different responses may mean they were responsible for a choice they could change; the internal conflicts of homophobia then seemed to become magnified. Cass' (1979) fourth stage of 
identity acceptance, is marked by an acceptance of a gay self-image with inner tension about the non-legitimatizing of their gayness. This might explain this conflict.

It was interesting that one student commented that she thinks about why she is gay "everyday," yet did not feel this was an important topic. It may be that she minimizes the issue because she is not comfortable with accepting her lesbianism. This indicates she may be tolerating, but not accepting her gay identity as described by Cass' (1979) third stage of identity tolerance.

Because these students are from a sub-population which is continually oppressed and victimized, they have become accustomed to accepting having just their basic needs met. Throughout the interviews, the students stated that they "just want simple acceptance" of who they are.

The comments about religion were very negative and are supported in the literature (McNeill, 1988). The students expressed themselves similarly to many other gays and lesbians. The church as an institution has a huge impact on society and its perpetuations of homophobia. As indicated in the literature (George \& Behrendt, 1987; Isensee, 1991; McNeill, 1988; Obear, 1990), oppression is perpetuated institutionally as well as individually.

In terms of specific developmental stage assessment, overall, the students seem to be spiraling, or back-and-forth, between two of Cass' (1979) stages: identity acceptance(stage four) and identity pride (stage five). In other words, in some instances one student seems to be at the fourth stage and, other times, that same student is in the fifth stage. This does not indicate a regression in stage progression, just a movement to adjust to particular environmental challenges.

In some settings, such as family and non-gay peer interactions, the students accept their identity, but seek more gay contact for their own validation. For 
example, one student stated "In my first year, I never spent time in my dorm except to sleep... Everyone acted so straight. " In other settings, like gay social interactions and gay-affirmative gatherings, they experience pride and are able to feel anger towards social intolerance. An example of this is this student's statement, "Some people saw me at a party with other gay people and I was afraid to go back to class."

In the coming out process, the students are between cognitive changes (stage two) and acceptance (stage three) according to Kus' (1990) model. They are trying to rid themselves of homophobia by learning about the gay world while passing as heterosexual (stage two) and, in some ways, they see their gay identities as a positive aspect of themselves (stage three). It seemed that in their thoughts or cognitions, that the students were more in the latter stage. For example, one student said "I came out to my family because I want them to know me as intimately as possible as their gay son." However, their behaviors were not always congruent of that and, in fact, were more indicative of the cognitive changes stage: "I haven't come to out to my extended family... if that is the only aspect which would upset them about me then I won't tell them." This movement, back and forth, seems to depend on the comfort level with particular environmental influences.

In terms of gay identity development, this study revealed several unmet criteria for identity formation. Missing from the experiences of these gay and lesbian students was affirmation of and information about their gayness, peer and family support, a niche in society for their career roles, a life span connection (connection from early messages of heterosexuality to adult lives of homosexuality), and role models. The implications are that much needs to change. Addressing these issues includes the following recommendations for action. 
Recommendations for those wishing to address these issues on campuses are specific and general. This study found that there is an apparent need for more awareness in residence halls, career services, and in classrooms. Overall, faculty and staff would do a great service to students if they increased professional awareness of the needs of gay and lesbian students on campus for recognition, inclusion, and support. Student development professionals have an awareness of students' needs in general, yet the traditional student development theories do not address the specific needs of this sub-population.

One recommendation is for programming about awareness of gay and lesbian students' needs in staff development sessions. This setting provides a captive audience and an opportunity for dialogue and discourse. It may be that awareness of gay and lesbian issues are not addressed unless intentionally and formally embodied in an agenda. Intentional discussions are critical in raising awareness and informing otherwise unaware campus community members.

Another recommendation includes specific programming in every department, residence hall and office on campus. Programming topics might include more than just awareness raising. Topics could address career concerns, civil rights, health concerns, peer relationships, marriage rights, parenting issues, and so on. The campus' counseling staff can provide support groups and individual counselors with training in specific gay needs. A student activities office could plan a dance which specifically invites gays and lesbians. The athletic department might organize a gay and lesbian softball tournament.

Not only would the programming be important, but the publicity generated would be visible to gay and lesbian students as well as others. This would be a way to display support for this population and validation of a gay identity. 
The different media resources on campus are effective in communicating to the masses. A campus radio station might include music performed and/or written for and about gays and lesbians. The campus newspaper could publish regular articles about gay and lesbian concerns or a calendar of social events. If there is a television station on campus, shows could include similar information.

The key word in these recommendations is "include." It is important for campuses to do more than simply recognize the existence of gays and lesbians. In order for them to feel integrated on campus, thus within their identity, they must be included in all aspects of campus life. This type of all-around inclusion may aiso reach out to those gay and lesbian students who otherwise would not seek out other gays and lesbians. For each gay and lesbian student who is "out of the closet," or at least accepting of their gay identity, there may be many more who are struggling for self-acceptance. Providing an environment which is gayaffirmative may encourage and support those students who wish to make more contact with other gays and lesbians.

By integrating established gay developmental theories, in-depth interviews and qualitative analysis of themes, issues, and concerns, the results of this research may educate and inform professionals on campuses and, in turn, may help to alleviate levels of intolerance. At this point, for the students in this study, the fight against their oppression still rests on their shoulders; they are the ones educating others and searching for ways to feel like a part of their campus. The recommendations in this research, might assist in shifting that responsibility to the appropriate campus professionals and away from the victims. As Reiter (1989) states, if there could be an atmosphere of uncritical acceptance of a gay person's sexuality, the gay identity would become more integrated into the overall sense of self. 
Further research might focus either on case studies or a larger and more random sample of the gay and lesbian undergraduate population. More exploration of the type of environmental changes needed would be beneficial in learning how to meet the needs of these students. A study of faculty and staff attitudes and beliefs about the gay and lesbian population would be helpful in understanding the current environment. 


\section{Appendix A \\ The University of Rhode Island \\ Department of Human Development, Counseling, and Family Studies \\ Transition Center \\ An Exploration of Psychosocial Develoomental /ssues of \\ Gay and Lesbian Underoraduate Students}

\section{Consent Form For Research}

I have been asked to participate in a research project as described below. The researcher will describe the project in detail. I should feel free to ask questions. I may contact Lee Peebles, the person mainly responsible for the study, at 596-3273 if I have questions after the interview.

I have been asked to take part in the study which will examine developmental issues that effect gay and lesbian undergraduate students. The study involves tape-recorded interviews of individual students and an assessment of the campus environment. The researcher will be observing and analyzing challenges of development as expressed by each student. The data gathered will be related to a specific model of identity development. This study is exploratory and has no hypothesis.

If I agree to participate in the study, I will be tape-recorded in an initial interview of approximately two hours with the possibility of a follow-up interview of the same length.

As a participant in the study, I may experience emotional discomfort. If this happens, I may quit immediately. I may consult with one of the resources in the attached list for assistance.

Although there may be no direct benefit to me for taking part in this study, the researcher may learn more about developmental challenges which gay and lesbian students face while undergraduates in college. The researcher may add to existing knowledge about this and further efforts encouraging and supporting these students in college campus environments.

My participation in this study is voluntary and confidential. None of the information will identify me by name. All interviews will be conducted without using names and will be labeled by date only. Interviews will be held in a confidential location. The researcher intends to keep the tapes confidential. I understand that for the purposes of the study direct quotes (with the sources remaining confidential) may be written in the final paper.

The decision to take part in this study is completely up to me. I do not have to participate. I may quit at any time. If I wish to quit, I simply inform Lee Peebles at 792-2568 of my decision.

If I am not satisfied with the way this study is performed, I may discuss my complaints with Lee Peebles or with Dr. Jayne Richmond at 792-5959, anonymously, if I choose.

I have read the Consent Form. The researcher Intends to keep the consent form confidentlal. My questlons have been answered. My signature on this form means that I understand the Information and I agree to particlpate In thls study.

Signature of Participant

Printed Name
Signature of Researcher

Printed Name

Date

Date 


\section{Appendix B}

\section{Support Resources \\ for Gay and Lesbian Concerns}

Counseling Center

Roosevelt Hall

University of Rhode Island

792-2288

Gay, Lesbian, and Bisexual Association

Memorial Union

University of Rhode Island

792-2398

Gay \& Lesbian Help Line of RI

Providence

751-3322

Health Services

Potter Building

University of Rhode Island

General Information 792-2246

AIDS Hotline $783-3920$

Office of Student Life

Memorial Union

University of Rhode Island

Dr. Diane Goodman, Coordinator of Human Relations Education

792-2101

Sexual Harrassment Committee

c/o Counseling Center

University of Rhode Island

Theodora A. Zubrinski, Chairperson

792-2288 


\section{Appendix C}

\section{Follow-up Interview Questions and Themes}

\section{Academic}

Do your classes discuss homosexual literature, authors, studies, etc. ?

Autonomy

Where do you live (non-specifically)?

Where do you get your information about events?

Acceptance-self

If you were heterosexual how would your life be different?

Do you accept yourself?

Do you ever feel like you have more that one life?

What are your most positive qualities? Negative?

Acceptance-others

How has your family dealt with your life choices?

Do your friends, family understand the life of a gay-lesbian?

Do you feel need for support from your family? Friends? Peers? Professors?

Health

AIDS concerns: What is the extent of your knowledge about AIDS?

Identification/Recognition

When did you realize your feelings of homosexuality?

To whom are you out?

Religion

Are you a member of a particular religious organization?

Safety

Have you experienced harassment?

Social Environment

What would you like to see on campus in terms of support, social,etc.?

Socializing/Integration

Discuss the make-up of your social group.

Do you participate in rallies, protests, dances, concerts?

Do you feel like a member of the campus community?

What types of co-curricular activities do you participate in?

Who do you live with (non-specific)? 


\section{Appendix C (cont.)}

\section{Support- peer}

What types of support do you have on campus?

Discuss the make-up of your social group.

\section{Support- professional}

What types of support do you have on campus?

What would you like to see on campus in terms of support, social, etc?

Have you spoken with a counselor, religious leader, faculty, etc. whom you felt understood your issues? 


\section{Bibliography}

Berzon, B. (1979). Positively aay. Los Angeles, CA: Mediamix Associates.

Cass. V. (1979). Homosexual identity formation: A theoretical model. Journal of Homosexuality. (4), (3), 219-235.

Chickering, A. (1969). Education and identity. San Francisco, CA: JosseyBass.

Comstock, G. (1991). Violence against lesbians and gay men. New York, NY: Columbia University Press.

Creamer, D. \& Associates (1990). College student development theory and practice for the 1990's. Alexandria, VA: American College Personnel Association.

Erikson, E. (1968). Identity: youth and crisis. In N. Evans \& V. Wall (Eds.), Bevond Tolerance: Gays Lesbians, and Bisexuals on Camous (pp. 131-146). Alexandria, VA: American Association of Counseling and Development.

Evans, N. \& Wall V. (Eds.). (1990). Beyond tolerance: gavs, lesbians, and bisexuals on campus. Alexandria, VA: American Association of Counseling and Development.

Fairchild, B. \& Hayward, N. (1989). What even parent should know about homosexuality. Orlando, FL: Harcourt Brace Jovanovich. 
George, K. \& Behrendt, A. (1987). Therapy for male couples. New York, NY: Haworth Press.

Hansen, G. (1982). Androgyny, sex-role orientation, and homosexism. Journal of Psychology. (112), 39-45.

Hanley-Hackenbruck, P. (1989). Psychotherapy and the "coming out" process. Journal of Gay \& Lesbian Psychotherapy (1)(1), 21-39.

Hetherington, C. (1990). Life planning and career counseling with gay and lesbian students. In N. Evans \& V. Wall (Eds.), Beyond Tolerance: Gays. Lesbians, and Bisexuals on Campus (pp. 131-146). Alexandria, VA: American Association of Counseling and Development.

Kinsey, A.C., Pomeroy, W.B., \& Martin, C.E. (1953). Sexual behavior in the human female. Philadelphia, PA: W.P. Saunders Co.

Kinsey, A.C., Pomeroy, W.B., \& Martin, C.E. (1948). Sexual behavior in the human male. Philadelphia, PA: W.P. Saunders Co.

Kus, R.J. (1988). Alcoholism and non-Acceptance of gay self. New York, NY: Haworth Press.

Isensee, R. (1991). Growing up gay in a dysfunctional family. Now York, NY: Prentice Hall Press. 
Larson, P. (1981). Sexual Identity and Self-Concept. Journal of Homosexuality, (7), (1), 15-32.

Maguen, S. (1991). Teen suicide: The government's cover-up \& America's lost children. The Advocate. Los Angeles,CA: Liberation Publications, Inc.

McNaught, B. (1988). On being gay. New York, NY: St. Martin's Press.

McNeill, J.J. (1988). Iaking a chance on God. Boston, MA: Beacon Press.

Obear, K. (1990). Homophobia. In N. Evans \& V. Wall (Eds.), Beyond Iolerance: Gavs.Lesbians, and Bisexuals on Campus (pp. 39-66). Alexandria, VA: American Association of Counseling and Development.

Patton, M. (1990). Qualitative evaluation and research methods. Newbury Park, CA: Sage Publications.

Reiter, L. (1989). Sexual orientation, sexual identity and the question of choice. Clinical Social Work Journal.(17), (2), 138-150.

Riddle, D. (1978). Relating to children: gays as role models. Jeurnal of Social Issues. (34), (3), 38-57.

Robinson, B.E. (1982). Gay men's and women's perceptions of early family life and their relationships with parents. Eamily Relations (31), (1), 79-83. 
Schneider, M.S. \& Tremble, B. Iraining service providers te work with gay and lesbian adolescents: A workshop.

Schoenberg, R. (1989). Unlockino closets in the ivory tower:Lesbian and gay identity formation and management in college. Paper presented at the meeting of the American College Personnel Association, Washington, D.C.

Shively, M. \& DeCecco, D. (1977). Components of sexual identity. Journal of Homosexuality.(3), (1), 41-48.

Troiden, R. \& Goode, E. (1980). Variables related to the acquisition of a gay identity. Journal of Homosexuality (4), 383-391.

Van Manen, M. (1990). Besearching lived experience. Ontario, Canada: The Althouse Press. 